\title{
PENGARUH LIKUIDITAS, SOLVABILITAS DAN UKURAN PERUSAHAAN TERHADAP AUDIT REPORT LAG
}

\author{
THE EFFECT OF LIQUIDITY, SOLVENCY AND FIRM SIZE ON AUDIT REPORT LAG
}

\author{
Nova Hari Setyawan \\ Universitas Islam Batik Surakarta - Surakarta \\ Email : novaharisetyawan@gmail.com
}

\begin{abstract}
ABSTRAK
Penelitian ini bertujuan untuk mengetahui pengaruh likuiditas, solvabilitas dan ukuran perusahaan terhadap audit report lag pada perusahaan sub otomotif dan komponen yang terdaftar di Bursa Efek Indonesia (BEI) periode 2016-2018. Jumlah sampel yang digunakan berjumlah 12 perusahaan menggunakan metode nonprobality sampling dengan teknik purposive sampling. Teknik analisis yang digunakan adalah regresi linear berganda. Hasil penelitian menunjukan bahwa (1) likuiditas tidak berpengaruh terhadap audit report lag. (2) solvabilitas berpengaruh terhadap audit report lag mengindikasikan bahwa tingginya jumlah hutang yang dimiliki perusahaan akan menyebabkan proses audit yang relatif lebih panjang, dan (3) ukuran perusahaan berpengaruh terhadap audit report lag yang mengindikasikan bahwa besar atau kecilnya jumlah aset yang dimiliki oleh perusahaan mempunyai mempengaruhi panjang atau pendeknya proses penyusunan laporan keuangan pada perusahaan tersebut.

Kata kunci : Likuiditas, Solvabilitas, Ukuran perusahaan, Audit Report Lag
\end{abstract}

\begin{abstract}
This study aims to determine the effect of liquidity, solvency and company size on audit report lag on sub-automotive companies and components listed on the Indonesia Stock Exchange (BEI) for the 2016-2018 period. The number of samples used was 12 companies with nonprobality sampling method with purposive sampling technique. The analysis technique used is multiple linear regression. The results showed that (1) liquidity not affected audit lag report. (2) solvency affects the audit report lag indicates that the high amount of debt owned by the company will cause a relatively longer audit process, and (3) the size of the company affects the audit report lag which indicates that the size of the assets owned by the company has affect the length or shortness of the process of preparing financial statements at the company.
\end{abstract}

Keywords: Liquidity, Solvency, Company size, Audit Report Lag 


\section{PENDAHULUAN}

Laporan keuangan merupakan sebuah catatan informasi keuangan pada perusahaan. Dimana informasi tersebut nantinya berguna sebagai bahan pertimbangan dalam pengambilan keputusan dan rencana bagi keberlanjutan usaha perusahaan. Audit Report lag diartikan keterlambatan dalam perlaporan laporan keuangan auditan.

Penelitian oleh Reni Yendrawati dan Varaby Wahyu Mahendra (2018) menunjukkan bahwa profitabilitas memiliki efek negatif pada laporan audit lag, sedangkan solvabilitas, likuiditas, ukuran perusahaan dan ukuran Akuntan Publik Ukuran perusahaan tidak mempengaruhi Audit laporan lag. Penelitian Yosia Taruli Mutiara, Adam Zakaria dan Ratna Anggraini (2018) menunjukkan penelitian pertama ukuran perusahaan memiliki pengaruh negatif dan signifikan terhadap laporan audit lag. Kedua, keuntungan perusahaan memiliki efek negatif dan signifikan terhadap laporan audit lag. Ketiga, solvabilitas tidak berpengaruh signifikan terhadap laporan audit lag, dan keempat, ukuran akuntan publik tidak berpengaruh signifikan terhadap laporan audit lag.

Penelitian Justita Dura (2017) menunjukkan bahwa profitabilitas berpengaruh terhadap audit report lag mengindikasikan bahwa perusahaan yang mendapatkan profit yang besar cenderung melakukan proses audit lebih singkat dibanding perusahaan yang mengalami profit yang kecil. Likuiditas berpengaruh terhadap audit report lag, (3) solvabilitas berpengaruh terhadap audit report lag mengindikasikan bahwa tingginya jumlah hutang yang dimiliki perusahaan akan menyebabkan proses audit yang relatif lebih panjang, dan ukuran perusahaan berpengaru untuk audit report lag bahwa besar atau kecilnya jumlah aset yang dimiliki oleh perusahaan mempunyai mempengaruhi panjang atau pendeknya proses penyusunan laporan keuangan pada perusahaan tersebut. Berdasarkan penelitian - penelitian sebelumnya yang menunjukan adanya ketidak konsistenan mengenai faktor - faktor yang mempengaruhi laporan audit report lag dengan memlih variabel Profitabilitas, Likuiditas, Solvabilitas dan Ukuran Perusahaan sebagai faktor yang mempengaruhi Audit Report Lag. Hal inilah yang menjadikan peneliti tertarik melakukan penelitian ini dengan judul "Pengaruh likuiditas, solvabilitas dan ukuran perusahaan terhadap audit report lag". Berdasarkan uraian pendahuluan diatas, maka perumusan masalah dalam penelitian ini adalah, antara lain 1) Apakah likuiditas berpengaruh terhadap audit report lag. 2) Apakah solvabilitas berpengaruh terhadap audit report lag. 3) Ukuran perusahaan berpengaruh negatif terhadap audit report lag.

\section{LANDASAN TEORI}

Teori Sinyal menurut Siwy Dan Ayu (2012), teori sinyal pengumuman yang diterbitkan dalam rangka memberikan sinyal bagi investor untuk membuat keputusan investasi. Keuntungan dan kerugian yang dihasilkan oleh suatu perusahaan akan menjadi kabar baik dan buruk di pasar modal. Dalam hal ini, keuntungan dapat memberikan sinyal positif yang mungkin untuk menarik investor, dan sebaliknya. Dengan demikian, teori ini mengatakan tentang drive perusahaan untuk memberikan informasi pihak eksternal dengan informasi.

Auditing memberi nilai plus bagi financial statement suatu entitas, karena pihak independen dan ahli dalam memeriksa laporan keuangan yaitu akuntan publik menjustifikasi wajar tidaknyafinancial statement. Menurut Sukrisno Agus (2012:2) pengertian auditing adalah pemeriksaann yang dilaksanakan kepada oknum yang independen dan dilakukan dengan teratur 
dan peka terhadap financial statement yang selesai dibukukan, bersama notes dan bukti/data pendukung, dengan maksud bisa memberi penilaian tentang wajar tidaknya financial statement.

Teori Audit Report Lag menurut Hayes (2014: 3-5), dalam melaksanakan tugas auditor, auditor memiliki tanggung jawab untuk merencanakan dan melakukan audit, sementara manajemen memiliki tanggung jawab atas laporan keuangan perusahaan dengan menerapkan kebijakan akuntansi yang sehat, membangun pengendalian internal , budidaya penelitian tentang laporan audit lag. Penelitian ini menguji faktor-faktor yang mungkin mempengaruhi laporan audit lag. Faktor-faktor yang dianggap memiliki pengaruh yang profitabilitas, solvabilitas, likuiditas, ukuran perusahaan dan ukuran Kantor Akuntan Publik.

Teori Likuiditas menurut Munawir (2001) likuiditas itu menunjukkan kemampuan suatu perusahaan untuk memenuhi kewajiban atau hutang-hutangnya pada saat ditagih. Artinya bahwa likuiditas merupakan suatu kemampuan untuk memenuhi kebutuhan jangka pendeknya. Current Ratio yang digunakan sebagai alat untuk mengukur likuiditas suatu perussahaan, serta sebagai petunjuk dalam mengetahui dan menduga sampai di manakah kemampuan sebuah perusahaan untuk memenuhi kewajiban keuangannya (Tunggal, 1995).

Solvabilitas adalah kemampuan suatu perusahaan dalam memenuhi segala kewajibannya. Kewajiban yang dimaksud di sini adalah utang-utang yang harus dibayarkan. Sedangkan rasio solvabilitas adalah perbandingan antara besarnya aktiva yang dimiliki perusahaan dengan utang-utang yang harus ditanggung. Dari rasio solvabilitas ini, kita bisa mengetahui sejauh mana perusahaan mampu melunasi utangnya jika perusahaan tersebut dilikuidasi. Pengertian solvabilitas menurut Sutrisno (2009) ialah kemampuan suatu perusahaan dalam memenuhi seluruh kewajibannya jika perusahaan dilikuidasi.

Ukuran perusahaan merupakan perbandingan besar atau kecilnya nilai suatu perusahaan. Ukuran perusahaan menggambarkan besar kecilnya perusahaan. Besar kecilnya usaha tersebut ditinjau dari lapangan usaha yang dijalanakan. Penentuan skala besar kecilnya perusahaan dapat ditentukan berdasarkan total penjualan, total asset, rata-rata tingkat penjualan (Seftianne, 2011). Sedangkan menurut Noverta dan Jogi (2012) menyatakan bahwa ukuran perusahaan menunjukkan seberapa besar dan kecil perusahaan ini. Indikator yang digunakan untuk melihat ukuran perusahaan yang nilai total aset, total penjualan, jumlah karyawan, anak perusahaan, dll.

\section{Pengembangan Hipotesis}

\section{Likuiditas terhadap Audit Report Lag}

Perusahaan yang memiliki tingkat likuiditas yang tinggi memiliki risiko yang lebih kecil terhadap kemungkinan terjadinya gagal bayar atas utang jangka pendek perusahaan (Listiana dan Susilo, 2012). Tingkat likuiditas yang tinggi menggambarkan perusahaan memiliki kinerja yang baik sehingga menghasilkan kabar baik (good news). Atas hal tersebut pihak manajemen akan meminta kepada pihak auditor untuk segera menyelesaikan laporan keuangan sehingga kabar baik (good news) dapat disampaikan secara tepat waktu.

\section{H1 : Pengaruh likuiditas berpengaruh terhadap audit report lag}

\section{Solvabilitas terhadap Auit Report Lag}

Ni Komang Ari Sumartini \& Ni Luh Sari Widhiyani (2014:405) menyatakan bahwa solvabilitas tidak berpengaruh signifikan terhadap Audit Report Lag. Walaupun sebuah perusahaan memiliki proporsi utang yang lebih besar, dalam penelitian ini tidak dapat 
membuktikan bahwa perusahaan tersebut harus memiliki tanggung jawab untuk dapat lebih cepat menyelesaikan audit laporan keuangannya.

\section{H2 : Pengaruh solvabilitas terhadap audit report lag Ukuran perusahaan terhadap audit report lag}

Ukuran dalam sebuah perusahaan merupakan sketsa besar kecilnya perusahaan yang ditentukan dari ukuran nominal seperti jumlah kekayaan dan total penjualan perusahaan dalam satu periode akuntansi (Rahayu 2011). Hubungan antara ukuran perusahaan dengan audit report lag merupakan ukuran dari sebuah perusahaan besar yang akan menyelesaikan proses auditnya lebih cepat dibandingkan perusahaan yang levelnya kecil atau menengah.

\section{H3 : Pengaruh ukuran perusahaan berpengaruh terhadap audit report lag}

\section{METODOLOGI PENELITIAN}

\section{Jenis dan Sumber Data Penelitian}

Jenis data yang digunakan dalam penelitian ini adalah data sekunder, yaitu data-data yang disediakan oleh pihak lain dan tidak berasal dari sumber langsung. Data yang diperoleh berupa laporan keuangan perusahaan sub sektor otomotif dan komponen yang terdaftar di Bursa Efek Indonesia. Populasi yang diamati dalam penelitian ini adalah seluruh perusahaan sub sektor otomotif dan komponen yang terdaftar di BEI pada periode 2016-2018. Pengambilan sampel dilakukan dengan metode purposive sampling. Jumlah populasi 13 yang memenuhi kriteria sebanyak 12 perusahaan, maka data penelitian $13 \times 3$ tahun yaitu 36 data

\section{Metode Analisis dan Hipotesisi Penelitian}

Pengujuan pertama dengan uji statistik deskriptif, Kemudian pengujian asumsi klasik sebagai salah satu syarat untuk bisa menggunakan persamaan regresi berganda adalah terpenuhinya uji asumsi klasik. Empat uji asumsi klasik dalam penelitian ini meliputi normalitas, multikolinearitas, autokorelasi, heteroskedastisitas. Penjelasan masing-masing pengujian asumsi klasik akan diuraikan seperti di bawah ini. Lanjutan pengujian untuk metode analisis yang digunakan untuk menguji pengaruh variabel bebas terhadap terikat dengan Uji T, Uji F dan Uji Determinasi

\section{Variabel dan Pengukuran}

Terdapat dua variabel yang digunakan dalam penelitian ini, diantaranya adalah variabel dependen dan independen. Variabel Dependen (Variabel Terikat) adalah variabel yang dipengaruhi, akibat dari adanya variabel bebas. Dikatakan sebagai variabel terikat karena variabel terikat dipengaruhi oleh variabel independen (variabel bebas). Variabel Dependen disebut juga dengan variabel terikat, variabel output, Konsekuen, variabel tergantung, kriteria, variabel terpengaruh, dan variabel efek. Variabel Independen (Variabel Bebas) adalah variabel yang mempengaruhi atau sebab perubahan timbulnya variabel terikat (dependen). Variabel Independen disebut juga dengan variabel perlakuan, kausa, risiko, variabel stimulus, antecedent, variabel pengaruh, treatment, dan variabel bebas. Dapat dikatakan variabel bebas karena dapat mempengaruhi variabel lainnya. Variabel independent dalam penelitian ini ada tiga, yaitu sebagai berikut : 
1. Variabel Dependen (Variabel Terikat)

Variable yang diakibatkan oleh variable bebas/ independen disebut variable Terikat/ Dependen. Pada riset ni, variable terikat/ dependen yang dipakai adalah Audit Report Lag. Audit Report Lag adalah lamanya waktu penyelesaian audit yang diukur dari tanggal penutupan tahun buku / akhir tahun fiskal hingga tanggal diterbitkannya laporan keuangan auditan (Soetedjo, 2006). Standar pengukuranya :

Audit Report Lag = Tanggal Lapor Auditor - Tanggal Tutup Buku

2. Variabel Independen (Variabel Bebas)

Variabel Independen adalah variable yang memengaruhi variable dependen. Variabel Independen di dalam penelitian ini meliputi:

a) Likuiditas

Likuiditas adalah kemampuan perusahaan dalam memenuhi kewajiban jangka pendeknnbya. Likuiditas merupakan salah satu faktor yang menentukan sukses atau kegagalan perusahaan. Penyediaan kebutuhan uang tunai dan sumber -sumber untuk memenuhi kebutuhan tersebut ikut menentukkan sampai mana perusahaan itu memegang resiko. Pengertian lain adalah kemampuan perusahaan untuk memenuhi kewajiban atau utang yang segera harus dibayar dengan harta lancarnya. Rasio likuiditas terdiri dari current ratio, quick ratio, cash ratio. Di bawah ini akan di jelaskan mengenai cara perhitungan rasio likuiditas. Rumus perhitungan current ratio adalah sebagai berikut:

aktiva lancar (current assets) : hutang Lancar (current liabilities)

Cara penghitungan quick ratio yaitu:

Quick ratio = (aktiva lancar - persediaan) $:$ utang lancar

Berikut adalah cara penghitungan cash ratio:

Cash ratio $=($ kas + surat berharga $):$ utang lancar

b) Solvabilitas

Menurut Fadoli (2014) menyatakan juga bahwa tingkat solvabilitas berpengaruh positif terhadap audit report lag. Peneliti mengukur variabel solvabilitas dengan menggunakan proksi Debt to Total Assets, proksi ini juga digunakan dalam penelitian Ramadhany (2018).

\section{Debt Total Assets $=$ Total Utang \\ Total Aktiva}

c) Ukuran Perusahaan

Ukuran dalam sebuah perusahaan merupakan sketsa besar kecilnya perusahaan yang ditentukan dari ukuran nominal seperti jumlah kekayaan dan total penjualan perusahaan dalamsatu periode akuntansi (Rahayu 2011).

\section{SIZE = LN (Total Aset)}




\section{HASIL DAN PEMBAHASAN}

\section{A. Deskripsi umum Data Penelitian}

Populasi yang digunakan dalam penelitian ini adalah sub otomotif dan komponen yang terdaftar di Bursa Efek Indonesia (BEI) periode 2016-2018 yang berjumlah 12 perusahaan dengan data statistic deskriptif pada variable penelitian.

Tabel. 1. Perusahaan yang Menjadi Sampel

\begin{tabular}{clc}
\hline No & Kriteria & Jumlah \\
\hline 1 & $\begin{array}{l}\text { Perusahaan sub otomotif dan komponen yang terdaftar di } \\
\text { BEl tahun 2016-2018 }\end{array}$ & 13 \\
2 & Perusahaan yang tidak menerbitan laporan keuangan & $(0)$ \\
3 & Laporan keuangan yang belum di audit & $(1)$ \\
4 & Tahun penelitian & 3 \\
5 & Jumlah observasi (12x3 tahun periode penelitian) & 36 \\
6 & Jumlah data yang di observasi & 36 \\
\hline
\end{tabular}

Sumber Data : Bursa Efek Indonesia

Pada penelitian ini, data yang digunakana adalah data sekunder berwujud annual report perusahaan sub otomotif dan komponen yang terdaftar di BEI tahun 2016-2018. Berikut Audit Report Lag, Likuiditas, Solvabilitas, Ukuran Perusahaan tahun 2016-2018 disajikan dalam table berikut.

Tabel. 2. Data tabulasi

Data tabulasi Audit Report Lag, Likuiditas, Solvabilitas, Ukuran Perusahaan tahun 20162018

\begin{tabular}{llllll}
\hline $\begin{array}{l}\text { Nama } \\
\text { Perusahaan }\end{array}$ & Tahun & ARL & Likuiditas & Solvabilitas & $\begin{array}{l}\text { Firm } \\
\text { Size }\end{array}$ \\
\hline ASII & 2016 & 58 & 123,94 & 0,87 & 33 \\
AUTO & 2016 & 51 & 150,51 & 0,39 & 30 \\
BOLT & 2016 & 45 & 768,07 & 0,15 & 28 \\
BRAM & 2016 & 81 & 189,08 & 0,5 & 29 \\
GDYR & 2016 & 88 & 86 & 1,01 & 28 \\
GJTL & 2016 & 83 & 173,05 & 2,2 & 31 \\
IMAS & 2016 & 82 & 92,42 & 2,82 & 31
\end{tabular}




\begin{tabular}{|c|c|c|c|c|}
\hline INDS & 2016 & 83 & 92,42 & 0,2 \\
\hline LPIN & 2016 & 88 & 71,35 & 0,89 \\
\hline MASA & 2016 & 86 & 105,36 & 0,8 \\
\hline PRAS & 2016 & 83 & 100,71 & 1,3 \\
\hline SMSM & 2016 & 88 & 286,03 & 0,43 \\
\hline ASII & 2017 & 58 & 122,86 & 0,89 \\
\hline AUTO & 2017 & 51 & 155,87 & 0,4 \\
\hline BOLT & 2017 & 61 & 312,7 & 0,65 \\
\hline BRAM & 2017 & 85 & 238,89 & 0,4 \\
\hline GDYR & 2017 & 86 & 86,07 & 1,31 \\
\hline GJTL & 2017 & 82 & 162,99 & 2,2 \\
\hline IMAS & 2017 & 81 & 83,77 & 2,38 \\
\hline INDS & 2017 & 85 & 512,54 & 0,14 \\
\hline LPIN & 2017 & 117 & 520,65 & 0,14 \\
\hline MASA & 2017 & 85 & 94,98 & 0,95 \\
\hline PRAS & 2017 & 113 & 95,71 & 1,28 \\
\hline SMSM & 2017 & 85 & 373,91 & 0,34 \\
\hline ASII & 2018 & 78 & 123,04 & 0,98 \\
\hline AUTO & 2018 & 51 & 145,21 & 0,45 \\
\hline BOLT & 2018 & 74 & 198,03 & 0,82 \\
\hline BRAM & 2018 & 81 & 218,51 & 0,42 \\
\hline GDYR & 2018 & 87 & 82,99 & 1,41 \\
\hline GJTL & 2018 & 88 & 150,05 & 2,53 \\
\hline IMAS & 2018 & 87 & 78,61 & 2,9 \\
\hline INDS & 2018 & 84 & 486,47 & 0,14 \\
\hline LPIN & 2018 & 88 & 1064,08 & 0,08 \\
\hline MASA & 2018 & 102 & 100,02 & 0,98 \\
\hline
\end{tabular}




\begin{tabular}{llllll} 
PRAS & 2018 & 84 & 109,96 & 1,11 & 28 \\
SMSM & 2018 & 86 & 354,54 & 0,35 & 29 \\
\hline
\end{tabular}

Sumber Data : Bursa Efek Indonesia

\section{B. Hasil Pengajuan Hipotesis dan Penelitian}

1. Statistik Deskriptif

Analisis statistik dekriptif digunakan untuk mengetahui dan menggambarkan data yang terkumpul, misalnya untuk mengetahui nilai maksimum, minimum, rata rata pada data yang digunakan dalam penelitian.

Tabel. 3. Statistik Deskriptif

\begin{tabular}{llllll}
\hline & N & Min & Max & Mean & $\begin{array}{l}\text { Std. } \\
\text { Deviation }\end{array}$ \\
\hline ARL & 36 & 45 & 117 & 80,42 & 15,810 \\
Likuiditas & 36 & 71,35 & 1064,08 & 225,3164 & 213,88366 \\
Solvabilitas & 36 &, 08 & 2,90 &, 9669 &, 79793 \\
Ukuran & 36 & 26,00 & 33,00 & 29,3333 & 1,74028 \\
perusahaan & & & & & \\
\hline
\end{tabular}

Sumber Data : BEI, Diolah dengan PSAW Statistics 18 (2019)

Berdasarkan hasil uji dengan jumlah sampel secara keseluruhan sebanyak 12 sampel yaitu :

1. Audit Report Lag mempunyai nilai minimum 45 dan nilai maksimum 117 dengan rata-rata sebesar 80,42 dan standar deviasi 15,810.

2. Likuiditas mempunyai nilai minimum 71,35 dan nilai maksimum 1064,08 dengan rata-rata sebesar 225,3164 dan standar deviasi 213,88366.

3. Solvabilitas memiliki nilai minimum ,08 dan nilai maksimum 2,90 dengan nilai rata-rata sebesar ,9669 dan standar deviasi sebesar ,79793.

4. Ukuran Perusahaan memiliki nilai minimum 26,00 dan nilai maksimum 33,00 dengan nilai rata-rata sebesar 29,3333 dan standar deviasi sebesar 1,74028 .

2. Uji Asumsi Klasik

\section{a. Hasil Uji Normalitas}

Menurut Ghozali (2011) Penggunaan Uji Normalitas berfungsi untuk menguji normal tidaknya model regresi variable RES. Riset ini menggunakan metode uji Kolmogrof Smirnov (k-s). Model regresi yang baik adalah terdistribusi normal atau mendekati. Apabila nilai $p$-value melebihi 0,05 maka data dikatakan normal, apabila nilai $p$-value kurang dari 0,05 maka data dikataan tidak normal. 
Tabel. 4. Uji Kolmogrov-Smirnov

\begin{tabular}{llll}
\hline Indikator & $p$-value & Tingkat signifikan & Keterangan \\
\hline $\begin{array}{l}\text { Asymp. Sig. (2- } \\
\text { tailed) }\end{array}$ & & $>0,439$ & Data terdistribusi \\
& & normal \\
\hline
\end{tabular}

Sumber Data : BEl, Diolah dengan PSAW Statistics 18 (2019)

Berdasarkan hasil uji $p$-value lebih besar dari nilai signifikasi $(0,439>0,05)$, maka kesimpulan yang terjadi adalah data terdistribusi normal.

\section{b. Hasil Uji Multikolinearitas}

Untuk menguji terdapat atau tidaknya korelasi antar variable bebas maka menggunakan multikoliniearitas. Model yang tidak terjadi multikolinearitas adalah model regresi yang baik (Ghozali, 2011). Cara mengetahui uji multikolinearitas dapat dari nilai pada tolerance dan VIF. Jika nilai tollerance lebih dari 0,1 dan VIF kurang dari 10 maka data lolos uji multikoliniearitas.

Tabel. 5. Uji Multikolinearitas

\begin{tabular}{llllll}
\hline $\begin{array}{l}\text { Variabel } \\
\text { Independen }\end{array}$ & Tollerance & $\begin{array}{l}\text { Cut } \\
\text { Off }\end{array}$ & VIF & Cit Off & Ket. \\
\hline Likuiditas & 104 & $>0,1$ & 1,487 & 10 & $\begin{array}{l}\text { Bebas } \\
\text { Multikolinearitas }\end{array}$ \\
Solvabilitas & 2,141 & $>0,1$ & 1,454 & 10 & $\begin{array}{l}\text { Bebas } \\
\text { Multikolinearitas }\end{array}$ \\
$\begin{array}{lllll}\text { Ukuran } \\
\text { Perusahaan }\end{array}$ & 3,374 & $>0,1$ & 1,372 & 10 & $\begin{array}{l}\text { Bebas } \\
\text { Multikolinearitas }\end{array}$ \\
\hline
\end{tabular}

Sumber Data : BEl, Diolah dengan PSAW Statistics 18 (2019)

Berdasarkan hasil uji bahwa semua variabel independen menunjukan nilai tolerance $>0,1$ dan VIF $<10$. Artinya, semua variabel independen yang digunakan dalam penelitian ini terbebas dari multikolinearitas

\section{c. Hasil Uji Autokorelasi}

Hasil autokorelasi dalam riset pengambilan keputusan dengan uji Durbin-Watson adalah sebagai berikut:

1) $\mathrm{DU}<\mathrm{DW}<$ 4-DU maka Ho diterima, maksudnya tidak terjadi autokorelasi.

2) $\mathrm{DW}<\mathrm{DL}$ atau DW $>4$-DL maka Ho ditolak, maksudnya terjadi autokorelasi.

3) $\mathrm{DL}<\mathrm{DW}<\mathrm{DU}$ atau 4-DU $<\mathrm{DW}<4$-DL, maksudnya tidak ada kesimpulan pasti.

Hasil uji akan disajikan dalam table berikut 
Tabel. 6. Uji Autokorelasi

\begin{tabular}{llll}
\hline Nilai DU & Nilai DW & Nilai 4-DU & Keterangan \\
\hline 1,651 & 1,483 & 2,348 & $\begin{array}{l}\text { Tidak Terjadi } \\
\text { Autokorelasi }\end{array}$
\end{tabular}

Sumber Data : BEI, Diolah dengan PSAW Statistics 18 (2019)

Berdasarkan hasil uji autokorelasi dengan metode Durbin-Watson menunjukan nilai DU < DW < 4-DU $(1,651<1,483<2,348)$, maka disimpulkan bahwa tidak ada autokorelasi.

\section{d. Hasil Uji Heteroskedastisitas}

Tujuan untuk Uji Heteroskedastisitas adalah mencari perbedaan varian residual antara pengamatan satu dan lainya. Jika varian satu observasi ke observasi lainya berbeda maka disebut heteroskedastisitas, apabila tidak maka disebut homoskedastisita, dengan kata lain jika $p$-value > nilai tingkat signifikan maka variabel independen terbebas dari heteroskedastisitas. Hasil uji regresi dikatakan baik jika tidak terjadi heteroskedastisitas.Metode korelasi Spearman's rho dipakai dalam pengujian ini.

Tabel. 7. Uji Heteroskedastisitas

\begin{tabular}{llll}
\hline $\begin{array}{l}\text { Variabel } \\
\text { Independen }\end{array}$ & $p$-value & $\begin{array}{l}\text { Tingkat } \\
\text { signifikan }\end{array}$ & Keterangan \\
\hline Likuiditas &, 570 & $>0,05$ & $\begin{array}{l}\text { Tidak terdapat } \\
\text { heteroskedastisitas }\end{array}$ \\
Solvabilitas &, 040 & $>0,05$ & $\begin{array}{l}\text { Tidak Terjadi } \\
\text { Heteroskedastisitas }\end{array}$ \\
$\begin{array}{l}\text { Ukuran } \\
\begin{array}{l}\text { Perusahaan } \\
\text { Ter }\end{array}\end{array}$ & & $>0,05$ & $\begin{array}{l}\text { Tdak Terjadi } \\
\text { Heteroskedastisitas }\end{array}$ \\
\hline
\end{tabular}

Sumber Data : BEI, Diolah dengan PSAW Statistics 18 (2019)

Berdasarkan hasil uji dapat dilihat bahwa seluruh variabel independen menunjukan $p$-value $>0,05$, yang artinya semua variabel independen tidak terdapat heteroskedastisitas.

3. Uji Hipotesis

\section{a. Model Regresi Berganda}

Analisis yang dalam riset ini menggunakan analisis regresi linear berganda yang dipakai untuk membuktikan pengaruh variabel independen terhadap variabel dependen. Hasil regresi linear berganda dalam analisis ini adalah sebagai berikut : 
Tabel. 8. Uji Regresi Berganda

\begin{tabular}{lll}
\hline Model & \multicolumn{2}{l}{ Unstandardized Coefficients } \\
\cline { 2 - 3 } & $\mathrm{B}$ & Std. Error \\
\hline (Constant) & 231,727 & 46,876 \\
Likuiditas &, 008 &, 013 \\
Solvabilitas & 7,623 & 3,560 \\
Ukuran Perusahaan & 5,350 & 1,586 \\
\hline
\end{tabular}

Sumber Data : BEl, Diolah dengan PSAW Statistics 18 (2019)

Audit Report lag $=231,727-, 008$ X1 + 7,623 X2 - 5,350 X3 + e Nilai konstanta sebesar 231,727. Ini menunjukkan bahwa jika nilai variabel bebas yaitu likuiditas, solvabilitas dan ukuran perusahaan sama dengan nol, maka tingkat audit report lag adalah sebesar 231,727 hari. Koefisien regresi likuiditas (X1) sebesar -,008. Ini menunjukkan bahwa jika variabel independen lainnya dianggap konstan, maka kenaikan 1 persen likuiditas akan mengakibatkan penurunan audit report lag sebesar ,008 persen. Koefisien regresi solvabilitas (X2) sebesar 7,623. Ini menunjukkan bahwa jika variabel independen lainnya dianggap konstan, maka kenaikan 1 persen solvabilitas akan mengakibatkan penurunan audit report lag sebesar 7,623 persen. Koefisien regresi firm size (X3) sebesar - 5,350. Ini menunjukkan bahwa jika variabel independen lainnya dianggap konstan, maka kenaikan 1 firm size akan mengakibatkan kenaikan audit report lag sebesar 5,350 persen.

b. Uji Metode Analisis

1. Uji Hipotesis (Uji t)

Tabel. 9. Hasil Uji t

\begin{tabular}{llllll}
\hline Model & T tabel & T hitung & p-value & syarat & Keterangan \\
\hline Likuiditas & 2,037 &, 575 &, 570 & $<0,05$ & Ditolak \\
Solvabilitas & 2,037 & 2,141 &, 040 & $<0,05$ & Diterima \\
Ukuran & 2,037 & 3,374 &, 002 & $<0,05$ & Diterima \\
Perusahaan & & & & & \\
\hline
\end{tabular}

Sumber Data : BEI, Diolah dengan PSAW Statistics 18 (2019)

Berdasarkan hasil uji t yang disajikan pada Tabel 10 bahwa nilai $\beta$ dengan signifikansi uji $t$ menunjukkan angka lebih kecil dari taraf nyata dalam penelitian ini yaitu 0,05 . Hal ini menunjukkan variabel solvabilitas, dan ukuran perusahaan berpengaruh terhadap audit report lag. Dengan demikian hipotesis $\mathrm{H} 2$, dan $\mathrm{H} 3$ diterima. 
2. Uji F

Tabel. 10. Hasil Uji F

\begin{tabular}{lllll}
\hline Fhitung & Ftabel & p-value & Signifikasi & Keterangan \\
\hline 4,346 & 2,89 & 0.011 & $<0,05$ & $\begin{array}{l}\text { Secara bersamaan } \\
\text { variabel berpengaruh } \\
\text { secara simultan }\end{array}$
\end{tabular}

Sumber Data : BEl, Diolah dengan PSAW Statistics 18 (2019)

Pada hasil pengujian menunjukkan bahwa $F$ hitung $>F$ tabel dan nilai Sig $<0.05$ yang artinya bahwa likuiditas, solvabilitas dan ukuran perusahaan memiliki pengaruh secara simultan terhadap audit report lag.

3. Uji Koefisien Derterminasi

Tabel. 11. Hasil Uji Derterminasi

\begin{tabular}{lllll}
\hline Model & $R$ & $R$ Squar & $\begin{array}{l}\text { Adjusted } \\
\text { Square }\end{array}$ & Std Error of the Estimate \\
\hline 1 & 0.538 & 0.289 & 0.223 & 13,937 \\
\hline
\end{tabular}

Sumber Data : BEl, Diolah dengan PSAW Statistics 18 (2019)

Hasil output diatas menunjukkan bahwa Adjusted R Square sebesar 0.289, artinya persentasi sumbangan pengaruh variabel likuiditas, solvabilitas dan ukuran perusahaan sebesar $28,9 \%$, sedangkan $71,1 \%$ dipengaruhi oleh variabel lainnya.

\section{Pembahasan}

\section{Likuiditas Tidak Berpengaruh Terhadap Audit Report Lag}

Hasil pengujian secara parsial membuktikan bahwa nilai thitung $<t_{\text {tabel }}$ $(0,575<2,037)$ dengan $p$-value sebesar 0,570 ( $p>0,05)$. Artinya, likuiditas tidak berpegaruh terhadap audit report lag. Kesimpulan dari hasil pegujian ini adalah variabel likuiditas tidak berpengaruh terhadap audit report lag maka $\mathrm{H} 1$ ditolak. Ini menunjukan bahwa tidak ada kesesuaian dengan teori yang ada, karena adanya ketentuan dari otoritas Jasa Keuangan yang mengharuskan setiap entitas melaporkan laporan keuangan auditan paling lama 90 hari setelah tanggal tutup buku.

\section{Solvabilitas Berpengaruh Terhadap Audit Report Lag}

Hasil pengujian secara parsial membuktikan bahwa nilai $t_{\text {hitung }}>t_{\text {tabel }}(2,141$ $>2,037)$ dengan $p$-value sebesar $0,040(p<0,05)$. Artinya, solvabilitas berpegaruh terhadap audit report lag. Kesimpulan dari hasil penelitian ini adalah $\mathrm{H} 2$ diterima.Hal ini disebabkan karena mengindikasikan bahwa tingginya jumlah hutang yang dimiliki perusahaan akan menyebabkan proses audit yang relatif lebih panjang. 


\section{Ukuran Perusahaan Berpengaruh Terhadap Audit Report Lag}

Hasil pengujian secara parsial membuktikan bahwa nilai $t_{\text {hitung }}>t_{\text {tabel }}$ $(3,374>2,037)$ dengan $p$-value sebesar $0,002(p>0,05)$. Artinya, ukuran perusahaan berpegaruh terhadap audit report lag. Kesimpulan dari hasil penelitian ini $\mathrm{H} 3$ Diterima. Hal ini disebabkan bahwa besar atau kecilnya jumlah aset yang dimiliki oleh perusahaan mempengaruhi panjang atau pendeknya proses penyusunan laporan keuangan pada perusahaan tersebut.

\section{REKOMENDASI KEBIJAKAN}

\section{Rekomendasi}

Berdasarkan hasil pengujian data yang diproses, maka rekomendasi hasil penelitian ini antara lain :

1. Untuk peneliti selanjutnya diharapkan dapat menambahkan sampel yang akan diteliti dengan meneliti lebih banyak perusahaan.

2. Peneliti juga dapat menambahkan variabel-variabel lain yang dapat menjelaskan audit report lag secara lebih luas.

\section{Kebijakan}

Bedasarkan hasil dan interpretasi penelitian ini, maka peneliti memberikan saran sebagai rekomendasi kebijakan antara lain :

1. Sampel yang digunakan dalam penelitian ini kurang banyak, yaitu hanya menggunakan 12 perusahaan sub otomotif dan komponen yang terdaftar di Bursa Efek Indonesia (BEI) periode 2016-2018.

2. Variabel independen yang digunakan hanya dapat menjelaskan vaariabel dependen sebesar $28,9 \%$, dari hasil tersebut dapat disimpulkan bahwa masih ada banyak variabel yang dapat mempengaruhi audit report lag. 


\section{DAFTAR PUSTAKA}

Andiyanto, R., Andini, R., \& P, P. D. (2017). Pengaruh Profitabilitas, Solvabilitas, Dan Ukuran Perusahaan Terhadap Audit Report Lag Dengan Reputasi KAP sebagai Variabel Moderating Pada Perusahaan Keuangan Yang Terdaftar Di Bursa Efek Indonesia Periode 2011-2015.

Ariani, K. R., \& Bawono, A. D. (2018). Pengaruh Ukuran dan Umur Perusahaan Terhadap Audit Report Lag dengan Profitabilitas dan Solvabilitas Sebagai Variabel Moderating. Riset Akuntansi dan Keuangan Indonesia .

Artaningrum, R. G., \& Budiartha, I. K. (2017). Pengaruh Profitabilitas, Solvabilitas, Likuiditas, Ukuran Perusahaan dan Pergantian Manajemen Pada Audit Report Perusahaan Perbankan. E-Jurnal Ekonomi dan Bisnis Universitas Udayana .

Dura, J., \& Dura, J. (2017). Pengaruh Profibilitas, Likuiditas, Solvabilitas, Ukuran Perusahaan Terhadap Audit Report Lag. JIBEKA , 64 - 70.

Hasanah, A. P. (2018). Pengaruh Profitabilitas, Solvabilitas, Likuiditas, Ukuran Perusahaan dan Reputasi Auditor Terhadap Audit Report Lag (Studi Empiris Pada Perusahaan Manufaktur yang Terdaftar Di Bursa Efek Indonesia Periode 2013-2016).

Munthe, SE.Ak.,M.Si.,C, I. L., \& Sepliyani. (2017). Pengaruh Komite Audit, Karakteristik Perusahaan, Dan Kualitas Auditor Terhadap Audit Delay PAda Perusahaan Manufaktur yang Terdaftar di Bursa Efek Indonesia Tahun 2012-2015.

Mutiara, Y. T., Zakaria, A., \& Anggraini, R. (2018). Pengaruh Ukuran Perusahaan, Laba Perusahaan, Solvabilitas Dan CPA Firm Size Terhadap Laporan Audit Lag. Journal Ekonomi Keuangan dan Akuntansi .

Perdana, R. Y. (2017). Pengaruh Profitabilitas, Solvabilitas, Struktur Kepemilikan, Kompleksitas Operasi Ukuran Perusahaan Terhadap Audit Report Lag (Studi Empiris Pada Perusahaan Manufaktur yang Terdaftar Di Bursa Efek Indonesia Periode 2013-2015).

Sartika, S. D. (2017). Pengaruh Profitabilitas, Likuiditas, dan Solvabilitas Terhadap Audit Report Lag (Studi Empiris Pada Perusahaan Perbankan Yang Terdaftar Di Bursa Efek Indonesia Tahun 2011-2015).

Tannuka, S. (2018). Pengaruh Ukuran Perusahaan, Profibilitas, Solvabilitas, Likuiditas, Dan Ukuran KAP Terhadap Audit Report Lag ( Studi Empiris Pada Perusahaan Properti, Real Estate, Dan Konstruksi Bangunan Yang Terdaftar Di Bursa Efek Indonesia Periode 2011-2015). Muara IImu Ekonomi dan Bisnis , hlm 354-368.

Yendrawati, R., \& Mahendra, V. W. (2018). Pengaruh Profitabilitas, Solvabilitas, Likuiditas, Ukuran Perusahaan dan Ukuran Umum. The International Journal of IImu Sosial dan Humaniora Invention , 5170-5178. 